University of Nebraska - Lincoln

DigitalCommons@University of Nebraska - Lincoln

January 2001

\title{
Geochemical Evolution of Ground Water in the Great Plains (Dakota) Aquifer of Nebraska: Implications for the Management of a Regional Aquifer System
}

\author{
David C. Gosselin \\ University of Nebraska - Lincoln, dgosselin2@unl.edu \\ F. Edwin Harvey \\ University of Nebraska - Lincoln, feharvey1@unl.edu \\ Carol D. Frost \\ University of Wyoming, Laramie, WY
}

Follow this and additional works at: https://digitalcommons.unl.edu/natrespapers

Part of the Natural Resources and Conservation Commons

Gosselin, David C.; Harvey, F. Edwin; and Frost, Carol D., "Geochemical Evolution of Ground Water in the Great Plains (Dakota) Aquifer of Nebraska: Implications for the Management of a Regional Aquifer System" (2001). Papers in Natural Resources. 140.

https://digitalcommons.unl.edu/natrespapers/140

This Article is brought to you for free and open access by the Natural Resources, School of at DigitalCommons@University of Nebraska - Lincoln. It has been accepted for inclusion in Papers in Natural Resources by an authorized administrator of DigitalCommons@University of Nebraska - Lincoln. 


\title{
Geochemical Evolution of Ground Water in the Great Plains (Dakota) Aquifer of Nebraska: Implications for the Management of a Regional Aquifer System
}

\author{
David C. Gosselin, ${ }^{*}$ F. Edwin Harvey, ${ }^{*}$ and Carol D. Frost ${ }^{\dagger}$ \\ * Conservation and Survey Division and School of Natural Resource Sciences, \\ University of Nebraska-Lincoln, 113 Nebraska Hall, Lincoln, NE 68588-0517 \\ † Department of Geology and Geophysics, P.O. Box 3006, \\ University of Wyoming, Laramie, WY 82071-3006
}

\begin{abstract}
The Great Plains (Dakota) aquifer system is one of the most extensive in North America, extending from the Arctic Circle to New Mexico, and underlies approximately $94 \%$ of Nebraska. In Nebraska, we do not have the physical ground water monitoring data at the scale that is necessary to manage ground water flow systems. However, first-order management strategies for this regional aquifer can be developed by understanding the geochemical evolution of the ground water. Using major-ion water chemistry data from 203 wells in 19 counties in eastern Nebraska, reconnaissance $\delta^{18} \mathrm{O}, \delta \mathrm{D}$, and $\delta^{87} \mathrm{Sr}$ data, and two geochemical models, PHREEQC and SNORM, we determine that modern meteoric water, $\mathrm{NaCl}$ brines from underlying formations, and cold glacial melt water are the primary sources for the water in the Dakota Aquifer. Based on these three water sources and the geochemical evolution of the various water types, the following first-order management strategies are suggested. In areas where $\mathrm{CaSO}_{4}$ and $\mathrm{Ca}-\mathrm{Na} \mathrm{SO}_{4}$ type water occur, Pleistocene-age glacial meltwater is the source. This water supply is not easily renewable. It is recommended that detailed water resource evaluation be conducted before extensive development occurs. The source of $\mathrm{Ca}( \pm \mathrm{Mg}) \mathrm{HCO} 3$ type water is from recharge by local precipitation and should be managed to maintain them as a renewable resource. In mixed ground water type areas, the ground water chemistry reflects the interaction of two distinct water types, one of which is meteoric water and the other is either $\mathrm{CaSO}_{4}$ and $\mathrm{Ca}-\mathrm{Na} \mathrm{SO}_{4}$-type water or $\mathrm{NaCl}$-type water. If the relatively fresh ground water is extracted at a rate that changes the location of the interface between the endmembers, then monitoring changes in water chemistry in a well over time could be used as an early warning system for the onset of potential problems related to overpumping.
\end{abstract}

\section{Introduction}

The Great Plains aquifer system (GPAS) is one of the most extensive in North America, extending from the Arctic Circle in Canada to New Mexico (Figure 1) (Helgesen et al. 1982; Jorgenson et al. 1993). In a stratigraphic context, the names Dakota Formation, Dakota Group, and Dakota Sandstone have all been used to refer to the Lower Cretaceous sandstones that comprise the GPAS in the western glaciated plains. Hence, the term Dakota aquifer system has also been used in reference to the GPAS. In this paper, we will refer to this system as the Dakota Aquifer because the name has local, as well as regional, name recognition and the GPAS terminology has not been generally adopted. The Dakota Aquifer includes stratigraphic units beyond the limits of the Dakota Formation. In addition to the Dakota Group, the system includes the Swan River Formation of Manitoba and eastern Saskatchewan, the Inyan Kara Formation and the Omadi Sandstone of the Plains states, and the Mannville Group of south-central Alberta and Saskatchewan.

The Dakota has generally been considered to be a classic example of an artesian aquifer system (Lennox et al. 1988). Upham (1895) and Darton (1905) proposed the analogy of pipe flow for ground water movement in the Dakota in which recharge enters sandstone beds in mountains to the west and discharges in the east where the sandstones outcrop or subcrop beneath the glacial drift. Current thinking about the source of ground water in and movement through the Dakota Aquifer indicates that the flow in the aquifer is far more complex (e.g., Jorgensen and Signer 1984). The complexities in the flow system are directly reflected in the natural spatial variations in ground water chemistry, in which extreme differences in water quality can occur on local scales (Rutulis 1984; Lawton et al. 1984). As a result, water quality strongly influences the use of the Dakota as a source of potable water.

The Dakota Aquifer underlies 94\% of Nebraska (Ellis 1984) and is utilized in two areas. In western Nebraska, oil, natural gas, and saline ground water are produced from the $\mathrm{D}$ and $\mathrm{J}$ sandstones in the upper parts of the Dakota Group (Figure 2). These oil producing zones extend to depths greater than 2,130 $\mathrm{m}$ (7,000 feet). In eastern and northeastern Nebraska, the sandstones within the Dakota Formation are used as a source of ground water where shallow Quaternary deposits cannot provide an adequate water supply. Lawton et al. (1984) indicated that 37 towns withdraw 


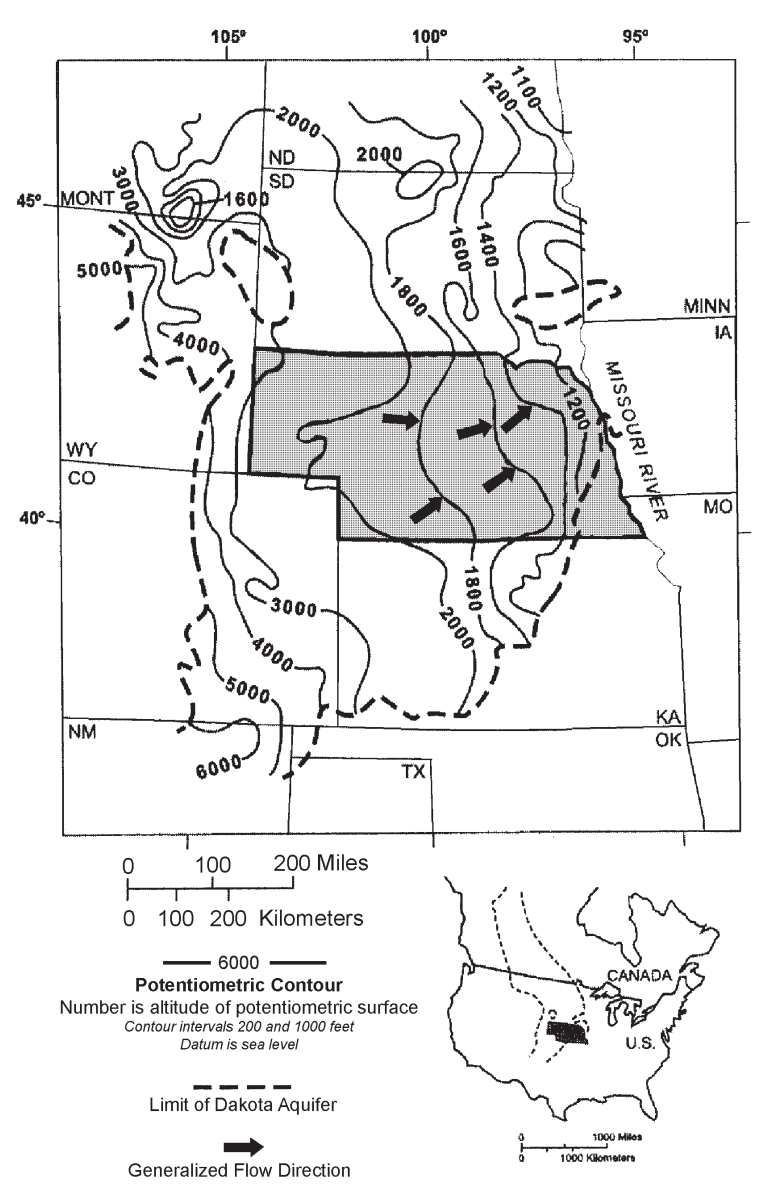

Figure 1. Extent of and recent potentiometric surface map of the Great Plains (Dakota) Aquifer in the region around Nebraska. The North American extent of the aquifer is shown at the lower right of the figure. (Modified from Leonard et al. 1984).

an estimated 22,710 to $30,280 \mathrm{~m}^{3}$ / day (6 to 8 million gal/day [mgd]) from the Dakota. Withdrawals for irrigation and industrial purposes were on the order of 102,195 and $7570 \mathrm{~m}^{3} /$ day (27 and $2 \mathrm{mgd}$ ), respectively. In the vicinity of Lincoln and Omaha, Nebraska's major metropolitan areas, urban expansion is placing increased demands on the Dakota aquifer system. Water quality is one of the primary constraints on the use of the Dakota as a source of water.

Although the demand on the Dakota Aquifer is increasing, we currently do not have an adequate understanding of the flow system(s) to develop appropriate management strategies. To develop these strategies, it is important to understand the movement of water into and through the ground water system. Unfortunately, ground water monitoring data does not exist at the scale that would be necessary to define spatial and vertical variations in the ground water flow systems. Although we do not have the physical ground water monitoring data, we do have a substantial archive of ground water chemistry data that can serve as a proxy record for the history of the ground water. Our basic hypothesis is that first-order management strategies can be developed by interpreting the geochemical evolution of the ground water using water chemistry data, geochemical modeling, and an understanding of the local as well as regional hydrogeologic framework.

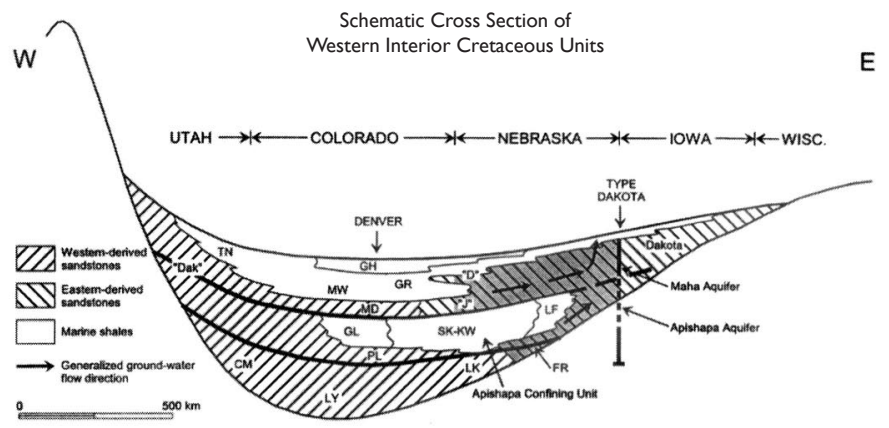

Figure 2. Schematic east-west cross section of Western Interior Cretaceous Units. The vertical scale is exaggerated, does not portray regional thickness patterns, and is generalized to display interpreted stratigraphic relations. Abbreviations as follows: DAK, Dakota Sandstone; TN, Tununk Shale; GH, Greenhorn Formation; MW, Mowry Shale; GR, Graneros Shale; D, D-sandstone; J, J-sandstone; SK-KW, Skull Creek and Kiowa Formations; LF, Longford Member; LK, Lakota Formation; LY, Lyne Formation; MD, Muddy Formation; GL, Glencairn Formation; PL, Plainview Formation; FR, Fall River Formation; CM, Cedar Mtn. Formation. Shading indicates those units present in Nebraska. The heavy black lines represent the base of major marine cycles. (Modified from Witzke and Ludvigson 1994.)

\section{Study Area and Regional Hydrogeologic Setting}

The study area consists of 19 counties in eastern Nebraska where the Dakota Aquifer is used as a primary or secondary source of water (Figure 3). In this paper, we use the stratigraphic nomenclature for the Dakota Formation provided in Witzke and Ludvigson (1994) and relate it to the hydrologic nomenclature of Jorgensen et al. (1993). Key characteristics of the Dakota Formation are that it had an eastern source for its sediments and it maintains its integrity across parts of Nebraska, South Dakota, North Dakota, Kansas, Iowa, and Minnesota. The eastern-derived sandstone- and siltstonedominated strata interfinger westward in the subsurface of western Nebraska, northeastern Colorado, and the central to eastern Dakotas with the marine strata of the Mowry and Belle Fourche shales (Figure 2; Witzke and Ludvigson 1994).

The Dakota Formation thickens from less than $30 \mathrm{~m}$ (100 feet) in eastern Colorado to $185 \mathrm{~m}$ (600 feet) in northeast Nebraska and exceeds $260 \mathrm{~m}$ (900 feet) in central Nebraska. The western limits of the Dakota Formation are operationally defined by the vertical cutoff where the Newcastle or J Sandstones form a tongue of eastern derived sediments with a sequence of marine shales (Witzke and Ludvigson 1994; Gries 1962). The Dakota Formation in the Nebraska panhandle is the westward extension of the clastic wedge that occurs in the eastern part of the state. In the western area, the D and J sandstone units at depths of $1,220 \mathrm{~m} \mathrm{(4,000} \mathrm{feet)} \mathrm{to} 1,830 \mathrm{~m}(6,000$ feet) are used for oil and gas production. These two oil producing sandstone units are separated by tens of feet of marine shales. The Dakota Formation of eastern Nebraska including the D and J sandstones in western Nebraska are part of the Maha Aquifer (Figure 2).

The Apishapa Aquifer (Figure 2), which is the lower of the two major aquifers of the GPAS, is not likely to occur extensively in eastern Nebraska (Jorgensen et al. 1993). It consists of permeable, partially cemented, medium to very finegrained sandstone. Although the Apishapa Aquifer may extend to some degree into the eastern half of Nebraska, it is likely to be in hydraulic connection with the overlying Maha Aquifer (Figure 2). 


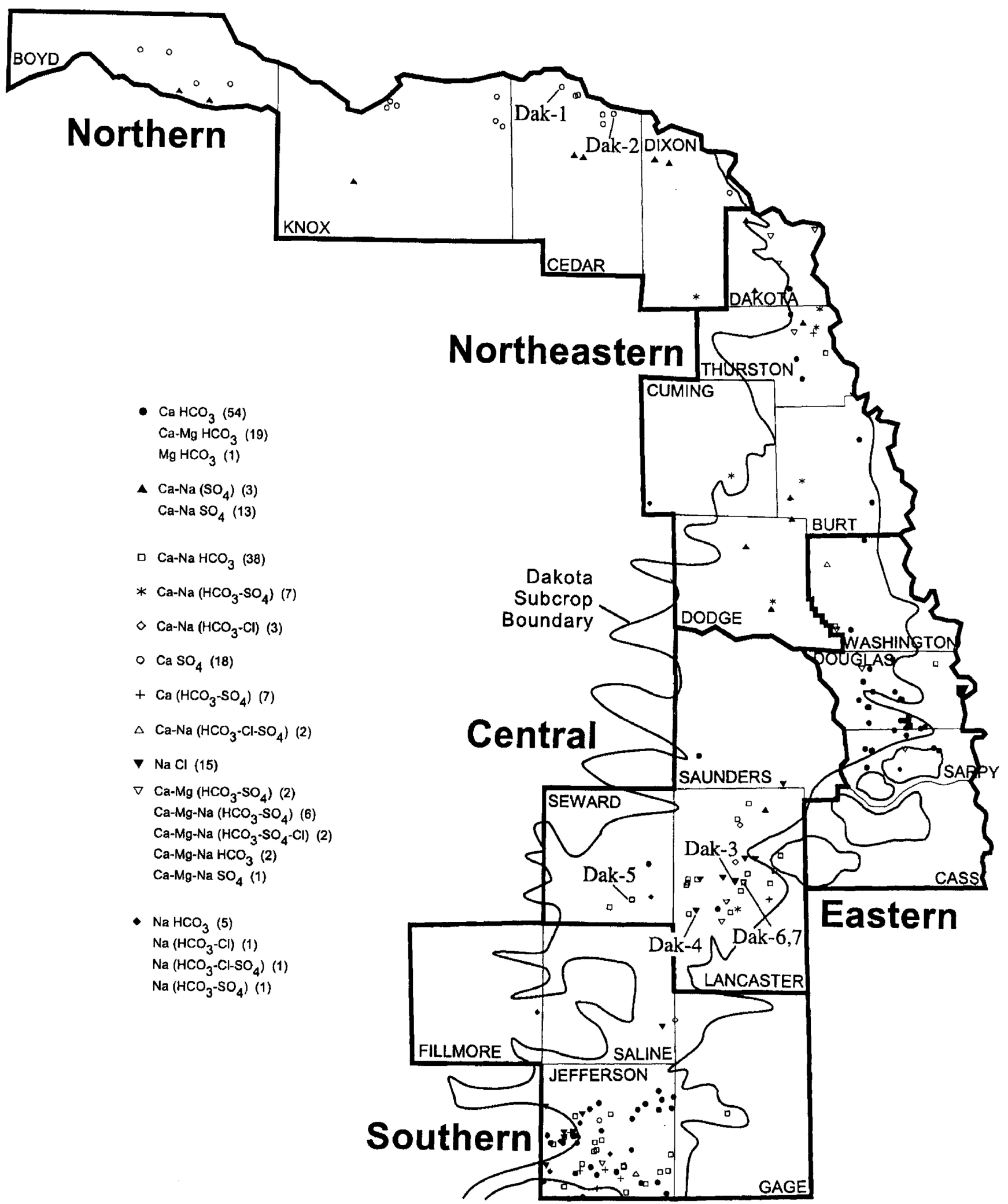

Figure 3. Sample locations and ground water chemistry type across eastern Nebraska by region.

The Apishapa confining unit (Figure 2), which is composed predominantly of the Kiowa Shale and the equivalent of the Skull Creek Shale, coincides with the eastern edge of the Kiowa-Skull Creek marine shales whereby the Apishapa confining unit does not occur in the eastern one-third of Nebraska.
In northern and northeastern Nebraska, the Dakota Formation is overlain, or partially overlain, by the Great Plains confining system composed predominantly of Upper Cretaceous marine shales that include the Graneros, Greenhorn, and other shale-dominated formations. Progressively southward, the Dakota Formation occurs in the subcrop 
and is overlain by Quaternary deposits consisting of glacial till and loess.

On a regional scale, hydraulic head in the Dakota progressively decreases from west to east (Figure 1; Helgesen $e t$ al. 1984). However, these estimates are primarily for where ground water in the Dakota is confined by the GranerosGreenhorn Shales. Where Quaternary units overlie the Dakota, the stratigraphic variability results in confined or unconfined conditions within the aquifer.

\section{Dakota Formation Stratigraphy of Eastern Nebraska}

The Dakota Formation in eastern Nebraska contains a highly variable series of sandstones and shales that reflect a complex pattern of deposition and erosion associated with alluvial, deltaic, and shoreline sedimentary environments along the eastern margin of the Cretaceous Western Interior Seaway. Witzke and Ludvigson (1994) have defined a general sequence for the Dakota Formation that includes a lower sandstone-dominated Nishnabotna Member and an upper mudstone-dominated Woodbury Member with sandstone channel bodies. From a hydrogeologic perspective, both of these members belong to the Maha Aquifer. The following descriptions are based on their work, except where indicated.

The Woodbury Member is recognized in northeast and east-central Nebraska. Its thickness ranges from 15 to $70 \mathrm{~m}$ in the east to about $120 \mathrm{~m}$ westward. Although the Woodbury strata is dominated by mudstones and shales, siltstone and sandstone bodies are present ranging in thickness from less than $1 \mathrm{~m}$ up to $25 \mathrm{~m}$. In the type Dakota area in northeast Nebraska, the Woodbury sandstones are dominantly very fine to fine grained.

In east-central Nebraska, especially between Omaha and Lincoln, the Woodbury Member is not recognizable and the continuous sandstone bodies of the Nishnabotna Member are the primary hydrostratigraphic unit. The Nishnabotna sandstones vary in thickness from 50 to $90 \mathrm{~m}$ in this area. The thickness of the Nishnabotna in Nebraska is not well constrained, but is highly variable and probably no more than $75 \mathrm{~m}$ thick. As a result of the down cutting by streams in eastern Nebraska, outliers of the Dakota as much as 130 $\mathrm{km}^{2}\left(50 \mathrm{mi}^{2}\right)$ in areal extent exist. Farther west and to the south, Nishnabotna and Woodbury members cannot be differentiated. Veatch (1969) indicated that the sandstone bodies are geometrically complex and discontinuously interbedded with shales.

In the northern part of the study area, the Dakota Formation is underlain primarily by Lower Paleozoic dolomite, with the exception of northern Knox County, where it rests on the Precambrian Sioux quartzite. From northern Burt and Cuming counties down into the middle of Lancaster and southern Seward counties, the Dakota rests on Pennsylvanian rocks. The Pennsylvanian rocks consist of alternating units of marine limestones and shales. Southward from Lancaster County into Kansas, the Dakota rests on Permian sedimentary rocks that are predominantly limestones and shales in southeastern Nebraska. However, younger Permian strata to the southwest also contain red beds and salt deposits.

\section{Methods}

In 1994, 11 samples were collected as part of a reconnaissance ground water study of the Dakota Formation. Samples Dak-1 through 7 were collected in eastern Nebraska. Samples Dak-8, 9, 11, and 12 were collected in western Nebraska from producing oil wells. All samples were analyzed for field parameters $(\mathrm{pH}$, total alkalinity, specific conductance, and temperature), as well as the major ions $\mathrm{Na}, \mathrm{K}, \mathrm{Ca}, \mathrm{Mg}, \mathrm{Cl}, \mathrm{SO}_{4}$, and $\mathrm{SiO}_{2}$. Total dissolved solids (TDS) were calculated. Samples were filtered through $0.45 \mu \mathrm{m}$ filters within six hours of sample collection. The major ions were analyzed using standard analytical protocol (Fishman and Friedman 1989) at the University of Nebraska-Lincoln Department of Agronomy laboratory. Duplicate samples, process blanks, and one blind standard were submitted to assure data quality. An additional data check included calculating charge balance. Nine of 11 samples had charge balances less than $\pm 5.2 \%$. The other two samples, Dak-3 and 12, had charge balances of $-11 \%$.

Aliquots of each sample were analyzed for $\delta^{18} \mathrm{O}, \delta \mathrm{D}$, and $\delta^{87} \mathrm{Sr}$. Stable isotope analyses were completed at the Environmental Isotope Laboratory (EIL) at the University of Waterloo. Oxygen determinations were made using a Micromass 903 triple collector SIRA mass spectrometer following the procedures of Epstein and Mayeda (1953). Deuterium determinations were made on a Micromass 602C mass spectrometer following the zinc reduction preparation method of Coleman et al. (1982). Oxygen and hydrogen results are reported as parts per thousand (\%) with respect to V-SMOW using the $(\delta)$ notation where

$$
\delta_{\text {sample }}=\left(\mathrm{R}_{\text {sample }}-\mathrm{R}_{\text {standard }}\right) / \mathrm{R}_{\text {standard }} \times 1000
$$

$\mathrm{R}_{\text {sample }}$ is the ratio of ${ }^{18} \mathrm{O} /{ }^{16} \mathrm{O}$ or ${ }^{2} \mathrm{H} /{ }^{1} \mathrm{H}$ in the sample, and $\mathrm{R}_{\text {standard }}$ is the ratio of the international standard. The analytical precision for $\delta^{18} \mathrm{O}$ and $\delta^{2} \mathrm{H}$ are $0.2 \%$ and $2.0 \%$, respectively.

Strontium isotope analyses were completed at the University of Wyoming. Sr was isolated using Sr Spec resin. Sr isotopic ratios were measured on a Micromass Secter 54 Thermal Ionization mass spectrometer. An average ${ }^{87} \mathrm{Sr} /{ }^{86} \mathrm{Sr}$ ratio of $0.710250 \pm 0.00001(2 \sigma)$ and a normalized ${ }^{88} \mathrm{Sr} /{ }^{86} \mathrm{Sr}=0.1194$ were measured for the NBS $987 \mathrm{Sr}$ standard. ${ }^{87} \mathrm{Sr} /{ }^{86} \mathrm{Sr}$ values are measured routinely at the 2-sigma level to $\pm 0.001 \%$ or better. Because small numerical differences in ${ }^{87} \mathrm{Sr} /{ }^{86} \mathrm{Sr}$ may be highly significant, we express the $\mathrm{Sr}$ compositions ratios as a per mil deviation from modern sea water. The following transformation, where the 0.70920 represents the ${ }^{87} \mathrm{Sr} /{ }^{86} \mathrm{Sr}$ for modern sea water, was used:

$$
\delta^{87} \mathrm{Sr}=\left(\left[{ }^{87} \mathrm{Sr} /{ }^{86} \mathrm{Sr} / 0.70920\right]-1\right) \cdot 1000
$$

The 11 samples were supplemented by data from the archives of the U.S. Geological Survey (USGS), an unpublished $\mathrm{Ph}$.D. dissertation on ground water in Jefferson County (Veatch 1969), and an unpublished M.S. thesis on ground water in Douglas, Sarpy, and Washington counties ( $\mathrm{O}^{\prime}$ Connor 1987). These sources provided 363 analyses of which 243 had a complete set of major ions and field parameters ( $\mathrm{pH}$, total alkalinity, temperature, $\mathrm{Na}, \mathrm{K}, \mathrm{Ca}, \mathrm{Mg}, \mathrm{Cl}, \mathrm{SO}_{4}$, and $\mathrm{SiO}_{2}$ ). One hundred and ninety-two wells were included in the 243 analyses. We used the most recent data for each well for our analysis. Where multiple analyses occurred, the reported 
Table 1. Major Ion, $\delta^{87} \mathrm{Sr}, \delta^{18} \mathrm{O}$, and $\delta \mathrm{D}$ Data for Reconnaissance Ground Water Samples from the Dakota Formation. (na indicates data is not available)

\begin{tabular}{|c|c|c|c|c|c|c|c|c|c|c|c|c|c|c|c|c|}
\hline $\begin{array}{l}\text { Study } \\
\text { Sample } \\
\text { Number } \\
\end{array}$ & $\begin{array}{c}\text { Water } \\
\text { Temp. } \\
\left({ }^{\circ} \mathrm{C}\right)\end{array}$ & $\mathrm{pH}$ & $\mathrm{Na}$ & $\mathrm{K}$ & $\begin{array}{c}-\mathrm{Ma} \\
\mathrm{Ca}\end{array}$ & $\begin{array}{r}r \text { Ions } \\
\mathrm{Mg} \\
\end{array}$ & $\begin{array}{r}(\mathrm{mg} / \mathrm{L}) \\
\mathrm{Cl}\end{array}$ & $\mathrm{HCO}_{3}$ & $\mathrm{SO}_{4}$ & $\mathrm{SiO}_{2}$ & $\begin{array}{l}\text { Total } \\
\text { Dissolved } \\
\text { Solids } \\
(\mathrm{mg} / \mathrm{L}) \\
\end{array}$ & $\begin{array}{c}\text { Water } \\
\text { Type }\end{array}$ & ${ }^{87} \mathrm{Sr} /{ }^{86} \mathrm{Sr}$ & $\delta^{87} \mathrm{Sr}$ & $\delta^{18} \mathrm{O}$ & $\delta \mathrm{D}$ \\
\hline Dak-1 & 18 & 7.0 & 44 & 16 & 230 & 40 & 47 & 160 & 710 & 10 & 1180 & $\mathrm{CaSO}_{4}$ & 0.71079 & 2.2 & -16.5 & -123 \\
\hline Dak-2 & 17 & 7.0 & 44 & 15 & 230 & 40 & 44 & 170 & 700 & 9.4 & 1170 & $\mathrm{CaSO}_{4}$ & 0.71019 & 1.4 & -17.1 & -127 \\
\hline Dak-3 & 15 & 6.7 & 4200 & 17 & 160 & 81 & 7900 & 330 & 770 & 22 & 13,310 & $\mathrm{NaCl}$ & 0.70880 & -0.56 & -8.6 & -67 \\
\hline Dak-4 & 13 & 7.3 & 520 & 8 & 88 & 19 & 800 & 300 & 100 & 26 & 1710 & $\mathrm{NaCl}$ & 0.70901 & -0.27 & -9.2 & -66 \\
\hline Dak-5 & 15 & 7.3 & 86 & 5 & 43 & 8 & 33 & 290 & 45 & 20 & 380 & $\begin{array}{l}\mathrm{Ca}-\mathrm{Na} \\
\mathrm{HCO}_{3}\end{array}$ & 0.70918 & -0.03 & -9.6 & -66 \\
\hline Dak-6 & 14 & 6.7 & 36 & 4 & 64 & 14 & 34 & 270 & 31 & 28 & 340 & $\begin{array}{c}\mathrm{CaNa} \\
\mathrm{HCO}_{3} \\
\mathrm{Ca}-\mathrm{Na}\end{array}$ & 0.70889 & -0.44 & -7.7 & -54 \\
\hline Dak-7 & 15 & 6.3 & 52 & 9 & 85 & 23 & 90 & 220 & 130 & 31 & 528 & $\begin{array}{c}\mathrm{HCO}_{3} \\
\mathrm{SO}_{4}-\mathrm{Cl}\end{array}$ & 0.70880 & -0.56 & -7.2 & -51 \\
\hline Dak-8 & na & 7.7 & 1850 & 7 & 7 & 1 & 1100 & 2300 & 460 & 36 & 4590 & $\mathrm{HCO}_{3}-\mathrm{Cl}$ & 0.70807 & -1.6 & -10.3 & -84 \\
\hline Dak-9 & 41 & 6.2 & 44,400 & 130 & 1820 & 400 & 70,500 & 230 & 2500 & 25 & 120,000 & $\mathrm{NaCl}$ & 0.70815 & -1.5 & -6.6 & -66 \\
\hline Dak-11 & 29 & 7.3 & 13,100 & 48 & 50 & 34 & 16,100 & 1900 & 2500 & 36 & 32,800 & $\mathrm{NaCl}$ & 0.70800 & -1.7 & -6.1 & -63 \\
\hline Dak-12 & 50 & 7.3 & 11,200 & 58 & 240 & 39 & 17,700 & 680 & 5700 & 36 & 35,300 & $\mathrm{NaCl}$ & 0.70826 & -1.3 & -7.4 & -64 \\
\hline
\end{tabular}

Table 2. Average Major Ion Concentrations for Water Types from the Dakota Formation in Eastern Nebraska. (Values for $\mathrm{F}, \mathrm{SiO}{ }_{2}$ $\mathrm{B}$, and Fe were not available for all samples.)

\begin{tabular}{|c|c|c|c|c|c|c|c|c|c|c|c|c|c|c|c|}
\hline \multirow{2}{*}{$\begin{array}{l}\text { Water } \\
\text { Type }\end{array}$} & \multirow{2}{*}{$\begin{array}{l}\text { Number } \\
\text { of Samples }\end{array}$} & \multirow{2}{*}{$\begin{array}{l}\text { Temp } \\
\left({ }^{\circ} \mathrm{C}\right)\end{array}$} & \multirow[b]{2}{*}{$\mathrm{pH}$} & \multirow[b]{2}{*}{$\mathrm{Na}$} & \multirow[b]{2}{*}{ K } & \multirow[b]{2}{*}{$\mathrm{Ca}$} & \multicolumn{6}{|c|}{ Major Ions (mg/L) } & \multirow{2}{*}{$\begin{array}{c}\text { B } \\
(\mu \mathrm{g} / \mathrm{L})\end{array}$} & \multirow{2}{*}{$\begin{array}{c}\mathrm{Fe} \\
(\mu \mathrm{g} / \mathrm{L})\end{array}$} & \multirow{2}{*}{$\begin{array}{c}\text { Total } \\
\text { Dissolved } \\
\text { Solids } \\
(\mathrm{mg} / \mathrm{L}) \\
\end{array}$} \\
\hline & & & & & & & $\mathrm{Mg}$ & $\mathrm{Cl}$ & $\mathrm{HCO}_{3}$ & $\mathrm{SO}_{4}$ & $\mathrm{~F}$ & $\mathrm{SiO}_{2}$ & & & \\
\hline $\mathrm{CaSO}_{4}$ & 16 & 17 & 7.4 & 59 & 17 & 220 & 40 & 55 & 157 & 624 & 1.5 & 11 & 229 & 2490 & 1110 \\
\hline $\mathrm{Ca}-\mathrm{Na} \mathrm{SO}_{4}$ & 16 & 16 & 7.4 & 157 & 27 & 210 & 47 & 82 & 218 & 753 & 2.1 & 8.9 & 581 & 3887 & 1400 \\
\hline $\mathrm{Ca}-$ and $\mathrm{Ca}-\mathrm{Mg} \mathrm{HCO}_{3}$ & $\mathrm{O}_{3} 73$ & 14 & 7.3 & 25 & 4.1 & 91 & 17 & 8.9 & 358 & 39 & 0.4 & 27 & 139 & 862 & 380 \\
\hline $\mathrm{NaCl}$ & 13 & 14 & 7.6 & 4612 & 18 & 152 & 64 & 6557 & 430 & 885 & 1.2 & 16 & 1592 & 1529 & 12,500 \\
\hline $\mathrm{Ca}-\mathrm{Na} \mathrm{HCO}_{3}$ & 36 & 13 & 7.1 & 60 & 5 & 77 & 13 & 32 & 310 & 65 & 0.4 & 28 & 243 & 1114 & 430 \\
\hline Other Types & 38 & & & & & & & & & & & & & & \\
\hline Total & 192 & & & & & & & & & & & & & & \\
\hline
\end{tabular}

values were usually within $10 \%$ of each other and there were not any apparent time-dependent trends in the data. In addition to the major ions, the USGS and Veatch (1969) included data for F, B, and, in some cases, Fe and Mn. All of the water samples were plotted on Piper diagrams (Piper 1944) and classified using the scheme of Davis and DeWeist (1966).

Two geochemical modeling programs, PHREEQC and SNORM, were used on selected samples to interpret the geochemical evolution of the ground water. We used PHREEQC (Parkhurst 1995) to calculate saturation indices and reaction paths. SNORM (Bodine and Jones 1986; Jones and Bodine 1987) computed the normative salt assemblage from the solute concentration data in a conventional water analysis. The salt norm can be visualized as the solid residuum that coexists with an infinitely small, last vestige of solution upon evaporation of the sample to dryness at $25^{\circ} \mathrm{C}$. Three major normative water categories can be identified: (1) meteoric or weathering norms, which are characterized by alkali-bearing sulfate and carbonate salts; (2) marine-like norms, which have a halite-bishofite-carnalite-kieserite-anhydrite association; and (3) diagenetic norms, which yield Ca-bearing chlorides (antarcticite and tachyhydrite) and sylvite.

\section{Results}

We discuss the results by geographic areas: northern, northeastern, eastern, central, southern, and western. Our reconnaissance data are given in Table 1 . The location of the water samples are shown on Figure 3 in the context of their water classification. Average values for the major water types are given in Table 2.

\section{Northern Area}

In northern Nebraska (Boyd, Knox, Cedar, and Dixon counties), $\mathrm{CaSO}_{4}$-type waters predominate along with some $\mathrm{Ca}-\mathrm{Na} \mathrm{SO}_{4}$ waters. Both of these water types are associated with the Dakota where it is overlain by confining shale units. The Ca-Na waters generally occur to the south of the Cadominated waters. The average TDS in the $\mathrm{CaSO}_{4}$ and Ca$\mathrm{Na} \mathrm{SO}_{4}$-type waters are 1100 and $1400 \mathrm{mg} / \mathrm{L}$, respectively.

Two $\mathrm{CaSO}_{4}$ samples, Dak-1 and 2, from Cedar County have $\delta^{18} \mathrm{O}$ of $-16.5 \%$ ond $-17.1 \%$ and $\delta \mathrm{D}$ values of $-123 \%$ ond $128 \%$ o (Table 1). These values fall along the Meteoric Water Line (MWL) (Figure 4), but are significantly depleted compared to modern precipitation (Figure 4; Harvey 1999), and 


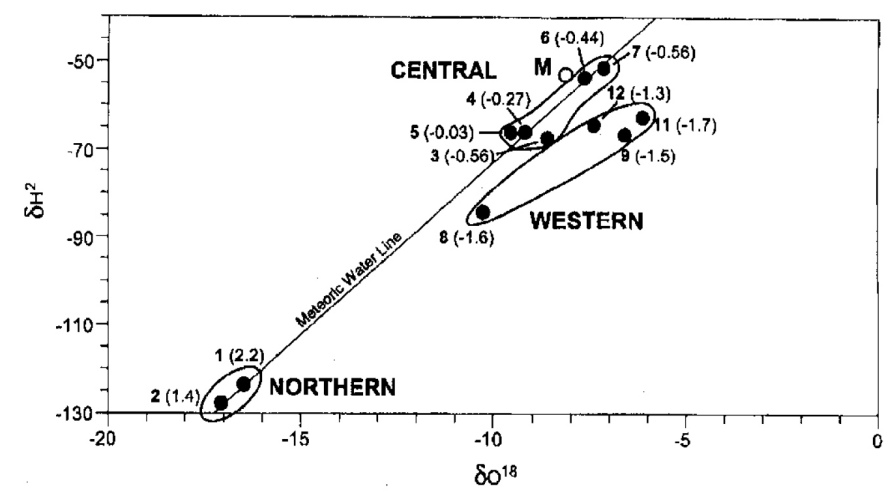

Figure 4. Plot of $\delta^{18} \mathrm{O}$ and $\delta^{2} \mathrm{H}$ values for Dakota ground water samples. Bold numbers represent sample numbers. Values in parentheses -() -are the $\delta^{87} \mathrm{Sr}$ for these samples. $\mathrm{M}=$ average $\delta^{18} \mathrm{O}$ and $\delta^{2} \mathrm{H}$ values for meteoric water in eastern Nebraska (Harvey 1999).

shallow ground water found elsewhere in Nebraska. The $\delta^{87} \mathrm{Sr}$ values for these two samples are $2.2 \%$ and $1.4 \%$, respectively.

\section{Northeastern Area}

Ground water in Dakota and Thurston counties are predominantly Ca-Na-SO $4^{\prime}$ Ca-Na $\left(\mathrm{HCO}_{3}-\mathrm{SO}_{4}\right)$, and $\mathrm{Ca}-\mathrm{Mg}-\mathrm{Na}$ $\left(\mathrm{HCO}_{3}-\mathrm{SO}_{4}\right) \pm \mathrm{Cl}$ waters and are associated with the subcrop contact between the Dakota Formation and overlying Cretaceous shales. In southern Thurston County and eastern Burt County, $\mathrm{CaHCO}_{3}$ waters become prevalent. Ca-Na-SO $\mathrm{S}_{4}$ and $\mathrm{Ca}-\mathrm{Na}\left(\mathrm{HCO}_{3}-\mathrm{SO}_{4}\right)$ waters occur in Cuming, Dodge, and western Burt counties. Total dissolved solids in Ca-Na $\mathrm{SO}_{4}$ waters range from 1200 to nearly $1900 \mathrm{mg} / \mathrm{L}$. Ca-Na $\left(\mathrm{HCO}_{3^{-}}\right.$ $\mathrm{SO}_{4}$ ) waters have TDS that range from 640 to $1120 \mathrm{mg} / \mathrm{L}$. $\mathrm{Ca}-\mathrm{HCO}_{3}$ and $\mathrm{Ca}-\mathrm{Mg}-\mathrm{Na}\left(\mathrm{HCO}_{3}-\mathrm{SO}_{4}\right) \pm \mathrm{Cl}$ waters have TDS generally less than $500 \mathrm{mg} / \mathrm{L}$.

\section{Eastern Area}

Waters from Washington, Douglas, and Sarpy counties are dominantly $\mathrm{Ca}-\mathrm{HCO}_{3}$ or $\mathrm{Ca}-\mathrm{Mg}-\mathrm{HCO}_{3}$ waters having TDS less than $500 \mathrm{mg} / \mathrm{L}$.

\section{Western Area}

Three of the four samples (Dak 9, 11, 12) collected from Scottsbluff, Morrill, and Cheyenne counties in western Nebraska are $\mathrm{NaCl}$ brines. TDS ranges from 33,000 to 120,000 $\mathrm{mg} / \mathrm{L}$. Dak-8 has a TDS of $4600 \mathrm{mg} / \mathrm{L}$ and is a $\mathrm{Na}\left(\mathrm{HCO}_{3}-\right.$ $\mathrm{Cl}$ )-type water. The $\mathrm{NaCl}$ waters have a relatively narrow range of $\delta^{18} \mathrm{O}$ and $\delta \mathrm{D}$ values, $-6.1 \%$ o to $-7.4 \%$ and $-63 \%$ to $-66 \%$, respectively. They fall along a trajectory that is consistent with evaporation. $\delta^{87} \mathrm{Sr}$ for these waters ranges from $1.3 \%$ o to $-1.7 \%$. Dak- 8 has a $\delta^{87} \mathrm{Sr}$ of $-1.6 \%$, which is similar to the $\mathrm{NaCl}$ waters, but distinct $\delta^{18} \mathrm{O}$ and $\delta \mathrm{D}$ values of $-10.3 \%$ and $-84 \%$, respectively.

\section{Central Area}

Ground water from the Dakota Formation in Lancaster, Saunders, and Seward counties are predominantly Ca-Na$\mathrm{HCO}_{3}$ and $\mathrm{NaCl}$-type waters. Other water types that occur include $\mathrm{Ca}-\mathrm{Na}\left(\mathrm{HCO}_{3}-\mathrm{Cl}\right), \mathrm{Ca}-\mathrm{Mg}\left(\mathrm{HCO}_{3}-\mathrm{SO}_{4}\right)$ and $\mathrm{Ca}-\mathrm{Na}$ $\left(\mathrm{HCO}_{3}-\mathrm{SO}_{4}\right) \pm \mathrm{Cl}$. The $\mathrm{Ca}-\mathrm{Na}-\mathrm{HCO}_{3}$ waters are dominantly to the east and south of Lincoln as well as to the west These waters have TDS that are generally less than $400 \mathrm{mg} / \mathrm{L}$ but range from 300 to $500 \mathrm{mg} / \mathrm{L}$. For Ca-Na- $\mathrm{HCO}_{3}$ - type waters Dak-5 and 6 (Table 1 ), the $\delta^{18} \mathrm{O}$ and $\delta \mathrm{D}$ values are $-9.6 \%$ and $-66.0 \%$ and $-7.7 \%$ and $-54.7 \%$, respectively. These data, along with Dak-7, fall along the MWL (Figure 4). The $\delta^{87} \mathrm{Sr}$ for these waters are distinct from those in the Northern area and range from $-0.3 \%$ to $-0.6 \%$. The $\mathrm{NaCl}$ waters, which occur in and around Lincoln, have TDS ranging from $1300 \mathrm{mg} / \mathrm{L}$ to more than $25,000 \mathrm{mg} / \mathrm{L}$. The $\delta \mathrm{D}$ and $\delta^{18} \mathrm{O}$ values for Dak-4 are $-65.8 \%$ and $-8.6 \%$, respectively, and they plot along the meteoric water line. Sample Dak-3 is displaced to slightly heavier $\delta^{18} \mathrm{O}$ values and falls along an evaporative trajectory. The $\delta^{87} \mathrm{Sr}$ values for Dak-3 and 4 are $-0.6 \%$ and $-0.3 \%$, respectively, and are distinctly different from the values from western Nebraska.

\section{Southern Area}

Ground water from the Dakota Formation in Fillmore. Saline, Gage, and Jefferson counties are predominantly Ca$\mathrm{HCO}_{3}, \mathrm{Ca}-\mathrm{Na} \mathrm{HCO}_{3}$, and $\mathrm{NaCl}$-type waters. The $\mathrm{NaCl}$ waters occur near the boundary between the Dakota Formation and overlying confining shales. The TDS of the $\mathrm{CaHCO}_{3}$ waters range from 315 to $530 \mathrm{mg} / \mathrm{L}$, with the majority of the values being less than $425 \mathrm{mg} / \mathrm{L}$. The $\mathrm{NaCl}$-type waters have TDS that ranges from 2100 to $13,000 \mathrm{mg} / \mathrm{L}$. The majority of the $\mathrm{Ca}-\mathrm{Na} \mathrm{HCO}_{3}$ waters have TDS less than $450 \mathrm{mg} / \mathrm{L}$ but range from 200 to $1060 \mathrm{mg} / \mathrm{L}$.

\section{Normative Mineral Assemblages}

For the $\mathrm{CaSO}_{4}$ waters, the normative mineral assemblage has greater than $50 \%$ anhydrite $\left(\mathrm{CaSO}_{4}\right), 10 \%$ to $26 \%$ polyhalite $\left(\mathrm{K}_{2} \mathrm{MgCa}\left(\mathrm{SO}_{4}\right)_{4} \cdot 2 \mathrm{H}_{2} \mathrm{O}\right)$ and bloedite $\left(\mathrm{Na}_{2} \mathrm{Mg}\left(\mathrm{SO}_{4}\right)_{2}\right.$ - $\left.4 \mathrm{H}_{2} \mathrm{O}\right)$, and $3 \%$ to $13 \%$ magnesite $\left(\mathrm{MgCO}_{3}\right)$. The $\mathrm{Ca}-\mathrm{Na}$ $\mathrm{SO}_{4}$-type waters have less than $43 \%$ anhydrite, $30 \%$ to $45 \%$ glauberite $\left(\mathrm{Na}_{2} \mathrm{Ca}[\mathrm{SO}]_{2}\right)$ and $7 \%$ to $10 \%$ magnesite. The $\mathrm{Ca}$ and $\mathrm{Ca}-\mathrm{Mg} \mathrm{HCO}_{3}$-type waters are dominated by calcite and dolomite, which comprise $70 \%$ to $75 \%$ and $60 \%$ to $70 \%$, respectively, of the normative assemblage. Aphthitalite $\left(\mathrm{K}_{3} \mathrm{Na}\left[\mathrm{SO}_{4}\right]_{2}\right)$ and thenardite $\left(\mathrm{Na}_{2} \mathrm{SO}_{4}\right)$ are $5 \%$ to $25 \%$ of the salt norm. When this percentage is less than 10, pirssonnite $\left(\mathrm{Na}_{2} \mathrm{Ca}\left[\mathrm{CO}_{3}\right]_{2}\right)$ becomes prevalent and comprises $16 \%$ to $41 \%$ of the normative assemblage.

For the $\mathrm{Ca}-\mathrm{Na} \mathrm{HCO}_{3}$-type waters, calcite and dolomite comprise $54 \%$ to $65 \%$ for the assemblage having subordinate and variable amounts of thenardite $(12 \%$ to $21 \%)$ and halite (10\% to $30 \%)$. NaCl-type waters are dominated by normative halite, which comprise $75 \%$ to $90 \%$ of the assemblage. The remaining part of the assemblage consists of less than $11 \%$ of each of the following mineral pairs: thenardite and glauberite, calcite and dolomite, or trona $\left(\mathrm{Na}_{3} \mathrm{H}\left[\mathrm{CO}_{3}\right]_{2} \cdot 2 \mathrm{H}_{2} \mathrm{O}\right)$ and burkeite $\left(\mathrm{Na}_{6} \mathrm{CO}_{3}\left[\mathrm{SO}_{4}\right]_{2}\right)$.

\section{Mineral Equilibrium}

Although there are at least five distinct water types that occur in the Dakota Formation, the calculated mineral saturation indices are similar. Chalcedony and quartz are typically in equilibrium (S.I. $=0 \pm 0.37$; Hitchon 1995) or slightly oversaturated. These indices reflect the quartz arenite to sublihtarenite characteristics of these first-cycle sandstones (Witzke and Ludvigson 1994). Carbonate and Fe-bearing minerals including pyrite and marcasite in the Dakota Formation are the most common authigenic cements and these are reflected in the saturation indices. Typically, calcite and dolomite are in equilibrium or slightly oversaturated. Dolomite is generally undersaturated. Fe-bearing species, such as $\mathrm{Fe}(\mathrm{OH})_{3}$, geo- 
thite $(\mathrm{FeOOH})$, and hematite $\left(\mathrm{Fe}_{2} \mathrm{O}_{3}\right)$, are strongly oversaturated. Siderite $\left(\mathrm{FeCO}_{3}\right)$ is variably saturated, ranging from strongly undersaturated to being at equilibrium.

\section{Discussion}

\section{Evolution of $\mathrm{CaSO}_{4}$ and Ca-Na $\mathrm{SO}_{4}$ Waters}

In northern Nebraska, the $\mathrm{Ca} \mathrm{SO}_{4}$ and $\mathrm{Ca}-\mathrm{Na} \mathrm{SO}_{4}$ waters occur where the Dakota is overlain by confining shale units. The $\delta \mathrm{D}$ and $\delta^{18} \mathrm{O}$ of these waters have values of $-125 \%$ and $-17 \%$, respectively, and are extremely depleted relative to modern precipitation and modern shallow ground water (Harvey, in press). However, they appear to be meteoric in origin (Figure 4). Using the $\delta^{18} \mathrm{O}-\mathrm{T}$ correlation of Harvey (in press), the depleted values for $\delta \mathrm{D}$ and $\delta^{18} \mathrm{O}$ in Cedar County suggest that mean yearly atmospheric temperatures during recharge were potentially $15^{\circ} \mathrm{C}$ colder than current conditions. There are at least three possible explanations for these apparently cold recharge values: (1) these waters originated in the high altitudes of the Front Range where yearly average temperatures are lower; (2) recharge is modern but represents $\delta \mathrm{D}$ - and $\delta^{18} \mathrm{O}$-depleted winter precipitation; and (3) recharge originated in eastern Nebraska but during a colder climate.

The current potentiometric surface (Helgesen et al. 1984) indicates that regional ground water flow is from the southwest to the northeast. Although a hydraulic connection may exist between the bedrock sediments in the Front Range in Colorado and the Dakota Aquifer of eastern Nebraska (Helgesen et al. 1984), it is unlikely that this connection passes beneath the Denver basin. Waters flowing deep in sedimentary basins encounter elevated temperatures and undergo isotopic exchange reactions with the aquifer materials, altering their $\delta \mathrm{D}$ and $\delta^{18} \mathrm{O}$ compositions (Clayton et al. 1966; Frape et al. 1984). Our samples from western Nebraska clearly reflect these types of alterations and are saline brines. If the ground water in the northern area had migrated from western Nebraska following the current potentiometric surface, we would not only expect altered $\delta D$ and $\delta^{18} \mathrm{O}$ compositions, but according to Carlson and Sibray (1992) TDS values greater than 10,000 mg/L occur in the Dakota Formation southwest of this area. If these high TDS waters are flowing to the northeast, the TDS values in the northern area should be similar to, or higher than the $10,000 \mathrm{mg} / \mathrm{L}$ value. This is not observed.

Three arguments can be made against the second explanation. First, less than $25 \%$ of precipitation occurs during the winter months. Second, the aquifer in this part of the state is for the most part confined. These two factors would minimize vertical recharge. Third, the modern hydraulic gradients do not favor deep recharge. Therefore it would seem that this part of the Dakota Formation was recharged with Pleistocene to Early Holocene glacial meltwater.

The isotopically light waters occur just south of the Missouri River, which is the boundary of the last major glacial advance. Siegel (1991), Siegel and Mandle (1984), and Matheney and Gerla (1996) have suggested the importance of recharge from glacial meltwater into bedrock aquifers. Prior to and during the deposition of Pleistocene glacial sediments (i.e., till, glaciolacustrine), the Dakota was subaerially exposed along the Sioux Ridge (Witzke et al. 1983). This configuration provided the opportunity for recharge of the Dakota Aquifer to occur along the base of overriding ice sheets many times during the Pleistocene. If these waters do repre- sent recharge from the north, then the potentiometric surface was opposite of what it is today (Stotler et al. 1999).

Although the predominance of anhydrite in the normative mineralogy could simply reflect dissolution of evaporitic gypsum, this is unlikely considering the depositional environment of the Dakota. A more likely interpretation is that these waters are the result of the oxidation of pyrite and the production of sulfuric acid to produce the abundant normative anhydrite. Pyrite is common in the upper Woodbury member and typically follows siderite in the Nishnabotna paragenetic sequence (Ludvigson et al. 1987). The weathering of pyrite produces an acidic solution enriched in iron and sulfate. In a natural neutralization process, this acidic solution dissolves additional calcite. Together these processes result in $\mathrm{CaSO}_{4}$ waters.

The abundant gypsum and glauberite in the norm for the $\mathrm{Ca}-\mathrm{Na} \mathrm{SO}_{4}$ waters not only reflects the importance of sulfaticweathering solutions, but also indicates the weathering of siliceous crystalline rocks having more calcic lithologies than those seen by the $\mathrm{CaSO}_{4}$ waters. Although we do not yet have stable isotope confirmation, we speculate that the Ca$\mathrm{NaSO}_{4}$ waters were also recharged by glacial melt water and represent $\mathrm{CaSO}_{4}$ waters that have evolved to more Na-rich compositions through ion exchange. This is consistent with the average $\mathrm{Na} /(\mathrm{Ca}+\mathrm{Mg})$ ratio for the $\mathrm{Ca}-\mathrm{Na} \mathrm{SO}_{4}$, which is 0.70 , being approximately two times greater than this ratio in the $\mathrm{CaSO}_{4}$ waters. For the exchange process to occur, clays must have been in contact with more saline waters having higher $\mathrm{Na} /(\mathrm{Ca}+\mathrm{Mg})$ ratios. The origin of the saline waters is not known, but the occurrence of saline brines having TDS greater than $10,000 \mathrm{mg} / \mathrm{L}$ to the south indicates that saline water has likely been available in the past. Commonly clays in saline environments will also have boron available for exchange. Boron concentrations in the $\mathrm{Ca}-\mathrm{Na} \mathrm{SO}_{4}$ waters are two times greater than those in the $\mathrm{CaSO}_{4}$ waters, which further supports the likelihood of ion exchange.

\section{Mixed Water Types in the Northeastern Area}

The Ca-Na $\mathrm{SO}_{4}$ waters occur where the Dakota is confined by the Cretaceous Carlile and Greenhorn-Graneros formations. These waters also occur in Dodge County. The Ca-Mg$\mathrm{Na}\left(\mathrm{HCO}_{3}-\mathrm{SO}_{4} \pm \mathrm{Cl}\right)$ and $\mathrm{Ca}-\mathrm{Na}$ or $\mathrm{Ca}\left(\mathrm{HCO}_{3}-\mathrm{SO}_{4}\right)$ waters are associated with the contact of the Dakota and the Graneros-Greenhorns formations, primarily in Dakota and Thurston counties. $\mathrm{Ca} \mathrm{HCO}_{3}$ waters occur in areas where the Dakota is overlain by Pleistocene glacial till and/or loess. The complex distribution of water types is likely related to the transition of the Dakota from a predominantly confined to an unconfined aquifer similar to that observed in Kansas. Macfarlane (1995) indicates that, as a result of thinning and erosional down cutting through the confining units overlying the Dakota Aquifer, there are variable degrees of recharge through the confining units and the establishment of local flow systems in Kansas. In relative terms, where the confining unit is thin or has been removed, the Dakota can receive a relatively greater amount of local recharge.

Based on the limited data, we propose the following scenario to explain the available data. Compositionally, the recharge waters are likely to be $\mathrm{CaHCO}_{3}$-type waters having relatively low TDS. Where the confining unit is thick and most coherent, the waters are $\mathrm{Ca}-\mathrm{NaSO}_{4}$ waters and represent the regional ground water flow component. As the confining unit 
thins and the vertical hydraulic conductivity allows for local recharge, the hydrogeologic conditions and associated water chemistry becomes more variable. The compositional relationships suggest that there may be interaction between the Ca$\mathrm{NaSO}_{4}$ endmember and a $\mathrm{CaHCO}_{3}$ endmember. The extent to which this mixing takes place is a function of dispersion and the time that the water has been in the aquifer. In addition, the interaction may have also been facilitated by the hypothesized changes in flow direction as a result of glaciation.

\section{Evolution of $\mathrm{CaHCO}_{3}$ and $\mathrm{Ca}-\mathrm{MgHCO}_{3}$ waters}

Waters from the eastern area are almost exclusively $\mathrm{CaHCO}_{3}$ and $\mathrm{Ca}-\mathrm{MgHCO}_{3}$ waters having TDS less than 500 $\mathrm{mg} / \mathrm{L}$. The Nishnabotna Member of the Dakota Formation is the predominant hydrogeologic unit in this area. The prevalent occurrence of calcite and dolomite along with pirsonnite as normative minerals suggests that carbonic acid hydrolysis of silicate minerals is the dominant process controlling the water chemistry. The saturation indices for the iron minerals also indicate their importance in controlling the iron concentrations in the water. The low TDS in these bicarbonate-dominated waters is consistent with these ground waters having been recharged relatively recently.

\section{Evolution and Source of $\mathrm{NaCl}$ Waters in Eastern Nebraska}

The $\mathrm{NaCl}$ waters occur in the vicinity of Lincoln, as well as near the contact between the Greenhorn-Graneros formations and the Dakota Formation in western Jefferson County. There are several possible mechanisms for the formation of these saline waters, which include: long-term water rock interaction; connate water in which the original water is removed, but solutes are retained by membrane filtration; evaporative concentration; and the dissolution of halite.

Ground water can only evolve to a Cl-rich brine if it encounters highly soluble chloride minerals. Although currently undersaturated with halite, the normative halite abundances (> 85\%) and $\mathrm{Na} / \mathrm{Cl}$ systematics (Figure 5) clearly support the conclusion that the salinity was derived from the dissolution of halite. It is unlikely that appropriate conditions existed for the formation of evaporites during the deposition of the Dakota Formation (Witzke and Ludvigson 1994). We therefore conclude that the saline water did not form as a result of water-rock interaction as the ground water migrated through the Dakota Formation.

As indicated, the $\mathrm{Na} / \mathrm{Cl}$ ratios are consistent with the dissolution of halite as well as the dilution or evaporation of sea water (Figure 5). The majority of $\mathrm{NaCl}$ waters have $\mathrm{Na}$ and $\mathrm{Cl}$ concentrations that are similar to modern sea water or fall along a line that represents the dilution of sea water. If these Dakota waters represent connate or diluted connate water, the normative mineralogy should be similar to that of sea water, which is characterized by about $77 \%$ halite along with normative carnallite $\left(\mathrm{KMgCl}_{3} \cdot 6 \mathrm{H}_{2} \mathrm{O}\right)$ and bischofite $\left(\mathrm{MgCl}_{2} \cdot 6 \mathrm{H}_{2} \mathrm{O}\right)$ (Jones and Bodine 1987). However, the normative mineralogy of our samples has greater than $85 \%$ halite and does not have any of the key normative index minerals for sea water, carnallite, and bischofite. These normative characteristics preclude connate sea water or a diluted sea water from being the source of the saline waters. The $\delta^{18} \mathrm{O}$ and $\delta \mathrm{D}$ data also suggest that these saline waters are similar to modern meteoric water and preclude evaporation as a major process in producing the observed salinity.

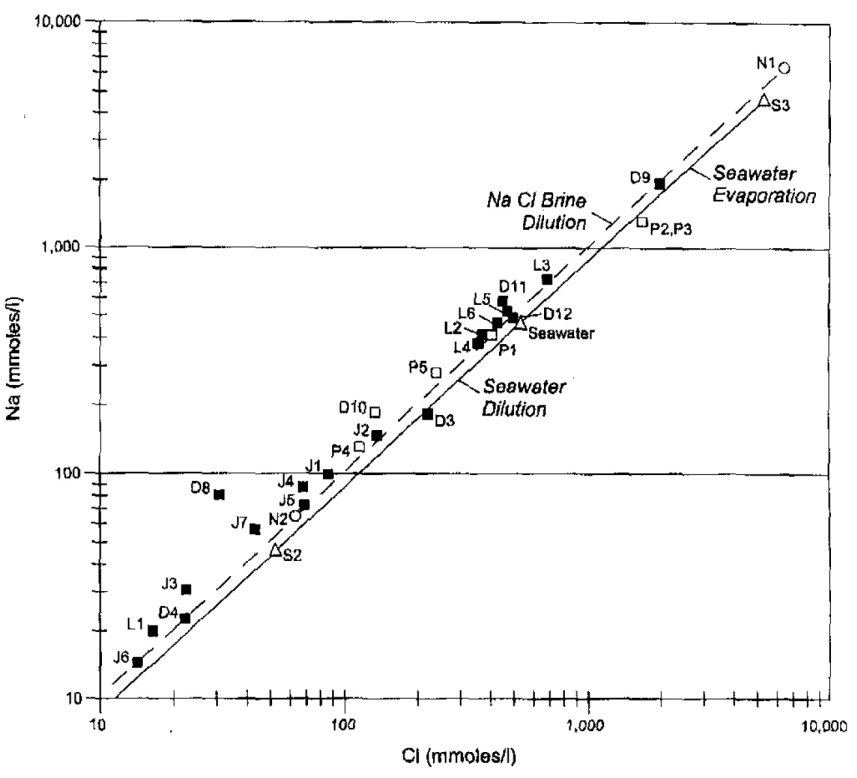

Figure 5. Plot of $\mathrm{Na}$ versus $\mathrm{Cl}$ for ground water used in this study. Open triangles $\Delta=$ values associated with sea water and its evaporation (S3) or dilution (S1). Open circles $\circ=$ values associated with the dissolution of halite (N1) and its corresponding dilution. Open squares $\square=$ ground water samples from the Pennsylvanian limestones. Closed squares = ground water samples from the Dakota Formation in Jefferson County (J), Lancaster County (L), and Table 1 (D).

In 1887 , a $751 \mathrm{~m}$ (2,463 feet) exploratory well was drilled in what is now west Lincoln. Three saline zones were identified during the drilling (Condra and Reed 1939). Zone 1 was in the lower part of the Dakota. The other two zones were in formations in the Pennsylvanian Shawnee Group (Lecompton-Oread formations) and the Kansas City Group (Drum Formation). Waters from these zones flowed to the surface under artesian conditions. Compositions of Pennsylvanian-derived $\mathrm{NaCl}$ waters and those in the Dakota are compared on Figure 5. The majority of the Dakota $\mathrm{NaCl}$ waters from Lancaster County have $\mathrm{Na}$ and $\mathrm{Cl}$ concentrations similar to the saline ground water in the Shawnee Group that was obtained from a well at the Lincoln Post Office (Figure 5). In addition, other characteristic ratios for the saline waters in the Dakota from Lancaster County compare well to those found in the Pennsylvanian waters, in particular, the $\mathrm{Ca} /\left(\mathrm{HCO}_{3}+\mathrm{SO}_{4}, \mathrm{Na} / \mathrm{Cl}\right.$, and the $\mathrm{SO}_{4} / \mathrm{Cl}$ ratios (Table 3). The average $\mathrm{Ca} / \mathrm{Mg}$ and $\mathrm{Mg} /$ $\mathrm{Cl}$ ratios of Dakota and Pennsylvanian waters are also within a factor of three. Based on these similarities, we speculate that these saline waters have a similar origin.

Condra and Reed (1939) indicated that the salt water from the Pennsylvanian zones cannot be the source of the saline waters in the Dakota because these zones are separated from the Dakota by "thick, impervious zones" that do not allow the saline fluids to move upward. This assumes that the integrity of these overlying beds is such that water is not allowed to move vertically. In other parts of the Dakota Aquifer, specifically in South Dakota, other workers have indicated that where pre-Cretaceous limestones underlie the Dakota they can be significant sources of water to this aquifer (Swenson 1968; Bredehoeft et al. 1983). Moreover, in the South Dakota area, Kolm and Peter (1984) argue for fracture controlled vertical leakage. Even without fractures, significant amounts of water can move vertically through rel- 
Table 3. Characteristic Molar Ratios for NaCl-Type Waters from the Dakota Aquifer Compared to Ratios from Saline Waters in Pennsylvania Limestones and Simulated by PHREEQC (See text for the details for each simulation.)

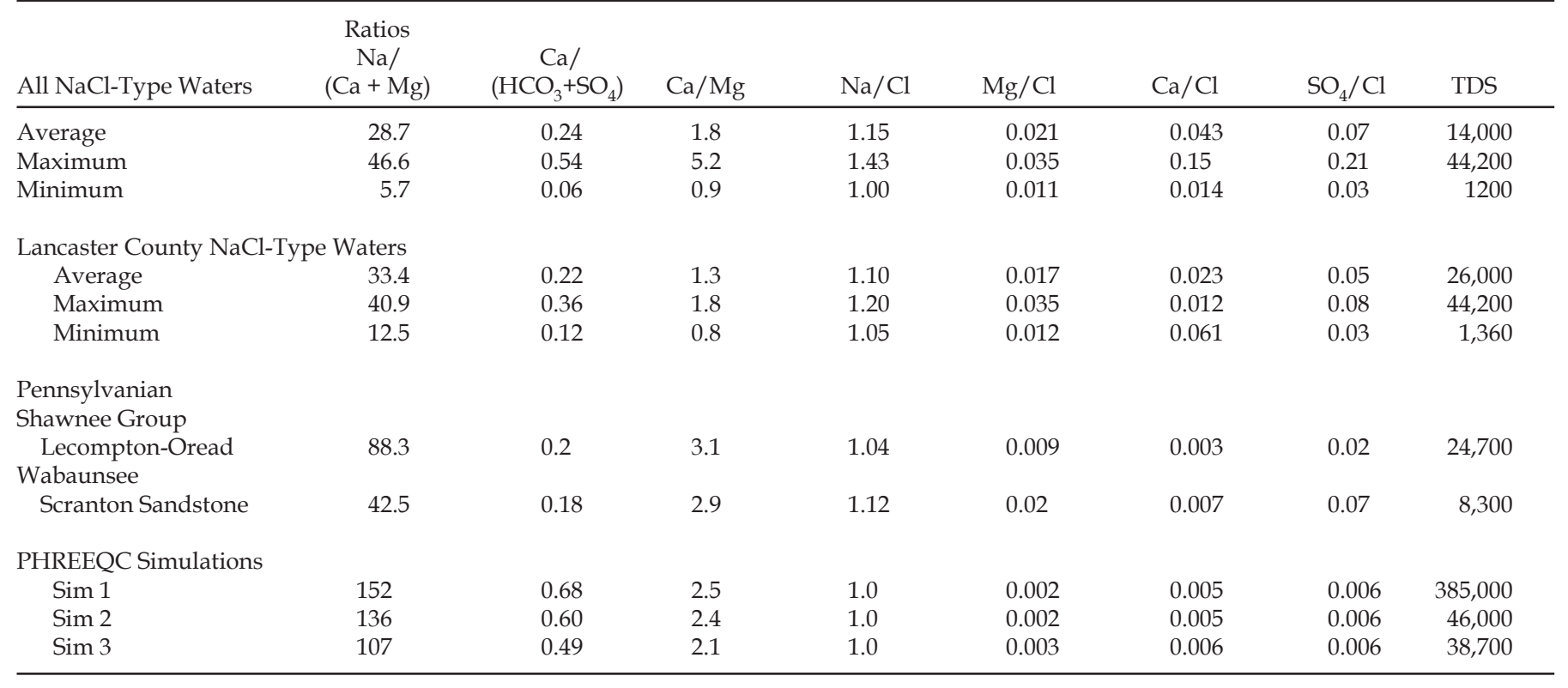

atively low conductivity layers because of the very large areas underlain by the Dakota (Swenson 1968; Helgesen et al. 1984). Fractures and faults are not uncommon in the pre-Cretaceous rocks of eastern Nebraska. More specifically, there is an east-to-west trending structural feature, known as the Denton Arch (Burchett 1982), that crosses the middle part of Lancaster County so that pathways for vertical migration of water from older units are certainly feasible. Because of the potential for vertical movement and the documented artesian conditions, our current conceptual model for the source of the saline waters is from the Pennsylvanian rocks.

The $\mathrm{Na}$ to $\mathrm{Cl}$ relationships (Figure 5) and the predominance of normative halite for the waters from the Pennsylvanian rocks strongly indicate that the salinity was derived from the dissolution of halite followed by dilution. These relationships are consistent with the geologic history of the Pennsylvanian rocks in Nebraska in which saline beds were deposited along with limestones and a variety of other marine facies as seaways became more restricted in western $\mathrm{Ne}$ braska (Carlson 1993).

Additional support for this origin of salinity comes from geochemical modeling using PHREEQC. Our simulation 1 (Table 3) involved a meteoric water equilibrated with $\mathrm{CO}_{2}$ in the atmosphere that initially interacts and comes into equilibrium with calcium carbonate at a $\mathrm{pCO}_{2}$ of 2.0. This water then was allowed to equilibrate with halite. As this water would continue to migrate through the Pennsylvanian rocks it would again equilibrate with calcium carbonate. In the context of molar ratios, the simulated values are generally within a factor of two of the actual values. The exceptions to this are the $\mathrm{Ca} /\left(\mathrm{HCO}_{3}+\mathrm{SO}_{4}\right)$ and the $\mathrm{SO}_{4} / \mathrm{Cl}$ ratios, which indicate that the assumptions regarding the evolution of $\mathrm{SO}_{4}$ could be improved. To account for differences in the simulated TDS, we diluted the brine with meteoric ground water, which had equilibrated with calcium carbonate. The dilution factors were 7:3 (simulation 2) and 9:1 (simulation 3). These dilutions bring the TDS within an order of magnitude of the observed values. In addition, it also brings the $\mathrm{Na} / \mathrm{Ca}$
$+\mathrm{Mg}$ ) and $\mathrm{Ca} / \mathrm{Mg}$ ratios progressively closer to the observed values. Additional dilution would be expected to bring them even closer to the observed values. Although these simulations are relatively simplistic, they are consistent with our current working hypothesis that waters in residence in the Pennsylvanian limestones have moved upward into the Dakota where they have been diluted and interacted with locally derived meteorically recharged ground water.

Although the $\mathrm{NaCl}$ waters in Jefferson County have $\mathrm{Na}$ / $\mathrm{Cl}$ ratios (Figure 5) and normative halite abundances consistent with halite dissolution, the geologic source of the saline water is probably different. In contrast to the Lincoln area where the Dakota is underlain by Pennsylvanian formations, Jefferson County is underlain by Permian strata. The Permian Cimmaron Series, which has halite deposits, occurs just west of the area where $\mathrm{NaCl}$-type waters have been observed. We speculate that these saline waters are a northward extension of the saline waters in Kansas that have a Permian source (Whittemore et al. 1993).

\section{Mixed Water Types in Lancaster and Jefferson Counties}

There are a variety of other water types in Lancaster and Jefferson counties that we currently attribute to varying degrees of interaction between $\mathrm{NaCl}$ waters and more recently recharged meteoric water. Recharge water of the $\mathrm{CaHCO}_{3}$ type having stable isotopic signatures similar to modern meteoric have apparently influenced the various water types in, at least, Lancaster County. The present and past occurrence of saline water in the Dakota Formation has likely resulted in significant quantities of sodium being adsorbed on the clays in the shales, siltstones, and sandstones. As fresh $\mathrm{CaHCO}_{3}$ waters slowly flush saline water from the aquifer, $\mathrm{Ca}$ and $\mathrm{Mg}$ are adsorbed and $\mathrm{Na}$ is released into the solution. The removal of $\mathrm{Ca}$ from the solution allows additional calcite, where available, to dissolve and supply additional calcium and bicarbonate to the water. Depending on the extent to which these processes have influenced $\mathrm{Na}, \mathrm{HCO}_{3}$, and $\mathrm{Ca}$ concentrations, a variety of waters could be produced. As 
was the case in northeastern Nebraska, another factor that will influence the extent to which these processes have taken place, particularly in Jefferson County, is the degree to which the Dakota Formation is confined. Similar explanations have been invoked in Kansas to explain the complex water chemistry related to Dakota Aquifer where it has been affected by saline water and the transition from a confined to unconfined aquifer (Whittemore et al. 1993).

\section{Management Implications}

A critical component to managing water resources is understanding the source of the ground water that is extracted from a well. According to our analysis, there are three distinct sources for the ground water in the Dakota that include modern meteoric water, $\mathrm{NaCl}$ brines from underlying formations, and glacial melt water. Based on these three water sources and our current understanding of the geochemical evolution of the various water types in the Dakota, we suggest the following first-order management strategies.

\section{$\mathrm{CaSO}_{4}$ and Ca-Na $\mathrm{SO}_{4}$-Type Water Areas}

The source of these waters, which are predominant in the northern and northeastern areas, is Pleistocene age glacial meltwater recharge (Stotler et al. 1999). These waters occur where the confining unit is thick and represent the confined ground water flow component. Where these waters occur, it is particularly important that overdevelopment does not occur. As the age of the water implies, the ground water extracted from wells in these areas is being removed from long-term aquifer storage. This water supply is not easily renewable. Because of the small population, the depth of the aquifer, the quality of the ground water and the topography, large scale aquifer development in this region is likely to be minimal. However, where these water types occur it is recommended that additional analysis of the resource be conducted before extensive development occurs.

\section{$\mathrm{Ca}( \pm \mathrm{Mg}) \mathrm{HCO}_{3}$-Type Water Areas}

The source of these ground waters is from recharge by relatively recent local precipitation. These waters occur where the Dakota Aquifer is unconfined. Development of the Dakota Aquifer as a water resource in these areas will be limited to the extent to which the ground water resource can be replenished by recharge from meteoric water. Because the ground water in these areas is linked to the local recharge conditions, it will be more susceptible to variations in seasonal or annual precipitation and should be managed accordingly to maintain it as a renewable resource.

\section{Mixed Ground Water-Type Areas}

These ground waters most often reflect the interaction of two distinct water types, one of which is meteoric water and the other is either $\mathrm{CaSO}_{4}$ and $\mathrm{Ca}-\mathrm{Na} \mathrm{SO}_{4}$-type water or $\mathrm{NaCl}$ type water. In areas such as Lancaster County, where meteoric recharge waters have likely displaced $\mathrm{NaCl}$ water downward, the vertical chemistry profile will be complex in which there will be a progression from relatively fresh $\mathrm{CaHCO}_{3}$ type water near the top to more saline, mixed ground water types to $\mathrm{NaCl}$ waters at depth. Although these complex vertical profiles have been observed, we cannot predict the vertical or spatial changes in water chemistry. If the fresher ground water is extracted at a rate that cannot be maintained by recharge, then the water chemistry will change as the interface between fresh and saline waters moves. From a water management perspective, monitoring changes in water chemistry in a well over time could be used as an early warning system for the onset of potential problems related to overpumping of the aquifer. In a similar fashion, where the aquifer is under varying degrees of confinement such as in northeast Nebraska, changes in ground water chemistry could be used to assess the extent to which a well is being influenced by water from the regional confined aquifer or local flow systems.

\section{Acknowledgments}

This research was supported by the University of NebraskaLincoln's Conservation and Survey Division and represents the Agricultural Research Division Journal Series No. 1342. Reviews by Drs. Ayers, Wigley, and Phillips plus two anonymous reviewers significantly improved the manuscript. D. Strickland's effort to the SALTNORM results are also appreciated.

\section{References}

Bodine, M. W., and B. P. Jones. 1986. The salt norm: A quantitative chemical-mineralogical characterization of natural waters. USGS Water Resources Investigations 86-4086.

Bredehoeft, J. D., C. E. Neuzil, and D. C. D. Milly. 1983. Regional flow in the Dakota aquifer: A study of the role of confining layers. USGS Water-Supply Paper 2237.

Burchett, R. R. 1982. Thickness and structure maps of the Pennsylvanian and Permian rocks in Nebraska. Nebraska Geological Survey Report of Investigations No. 7. Conservation and Survey Division, University of Nebraska-Lincoln.

Coleman. M. L., T. J. Shepherd, J. J. Durham, J. E. Rouse, and G. R. Moore. 1982. Reduction of water with zinc for hydrogen isotope analysis. Analytical Chemistry 54, 993-995.

Condra, G. E., and B. C. Reed. 1939. Deep wells at Lincoln, Nebraska. Nebraska Geological Survey Paper 15. Conservation and Survey Division, University of Nebraska-Lincoln.

Carlson, M. P. 1993. Geology, geologic time and Nebraska. Educational Circular No. 10. Conservation and Survey Division, University of Nebraska-Lincoln.

Carlson, M. P., and S. B. Sibray. 1992. Older ground water reservoirs in Nebraska. Contract Report for Nebraska Department of Environmental Quality. Conservation and Survey Division, University of Nebraska-Lincoln.

Clayton, R. N., D. L. Friedman, D. L. Graf, T. K. Mayeda, W. F. Meents, and N. F. Shrimp. 1966. The origin of saline formation water 1. Isotopic composition. Journal of Geophysical Research 71, 3869-3882.

Darton, N. H. 1905. Geology and underground water resources of the central Great Plains. USGS Professional Paper 32.

Davis, S. N., and R. J. M. DeWeist, 1966. Hydrogeology. New York: John Wiley and Sons.

Ellis, M. J. 1984. Overview of Dakota aquifer system in Nebraska. In Geohydrology of the Dakota Aquifer, Proceedings of the C. V. Theis Conference on Geohydrology, ed. D. G. Jorgensen and D. C. Signor, 4855. Worthington, Ohio: National Water Well Association.

Epstein, S., and T. K. Mayeda. 1953. Variations of the ${ }^{18} \mathrm{O} /{ }^{16} \mathrm{O}$ ratio in natural waters. Geochimica et Cosmochimica Acta 50, 1561-1563.

Fishman, M. J., and L. C. Friedman (eds.). 1989. Methods for the determination of inorganic substances in water and fluvial sediments. Techniques of Water-Resource Investigations of the U.S. Geological Survey, Book 5, Chapter A1. 
Frape, S. K., P. Fritz, and R. H. McNutt. 1984. Water-rock interaction and chemistry of ground waters from the Canadian Shield. Geochimica et Cosmochimica Acta 48, 1617-1627.

Gries, J. P. 1962. Lower Cretaceous stratigraphy of South Dakota and the eastern edge of the Powder River Basin. Symposium on Early Cretaceous Rocks of Wyoming. Wyoming Geological Association, GWDE book, 163-172.

Harvey, F. E. 1999. Evaluating ground water recharge models in Nebraska using stable oxygen and hydrogen isotopes. Geological Society of America Annual Meeting, October 25-28, Denver, Colorado. Abstracts with Programs 31, no, 7; A-349.

Harvey, F. E. in press. Use of NADP archive samples to determine the isotope composition of precipitation. Characterizing the meteoric input function for use in ground water studies. Ground Water.

Helgesen, J. O., D. G. Jorgensen, R. B. Leonard, and D. C. Signor. 1982. Regional study of the Dakota Aquifer (Darton's Dakota revisited). Ground Water 20, 410-414.

Helgesen, J. O., D. G. Jorgensen, R. B. Leonard, and D. C. Signor. 1984. Regional study of the Dakota Aquifer (Darton's Dakota revisited). In Geohydrology of the Dakota Aquifer, Proceedings of the C. V. Theis Conference on Geohydrology, ed. D. G. Jorgensen and D. C. Signor, 69-76. Worthington, Ohio: National Water Well Association.

Hitchon, B. 1995. Flourine in formation waters, Alberta Basin, Canada. Applied Geochemistry 10, 357-367.

Jones, B. F., and M. W. Bodine. 1987. Normative salt characterization of natural waters. In Saline Water and Gases in Crystalline Rocks, ed. P. Fritz and S. K. Frape, 5-18. Geological Association of Canada Special Paper 33. St. John's, Newfoundland.

Jorgensen, D. G., J. O. Helgesen, and J. L. Imes. 1993. Regional aquifers in Kansas, Nebraska, and parts of Arkansas, Colorado, Missouri, New Mexico, Oklahoma, South Dakota, Texas, and WyomingGeohydrologic framework. USGS Professional Paper 1414-B.

Jorgensen, D. G., and D. C. Signor (eds.). 1984. Geohydrology of the Dakota Aquifer, Proceedings of the C. V. Theis Conference on Geohydrology. Worthington, Ohio: National Water Well Association.

Kolm, K. E., and K. D. Peter. 1984. A possible relation between lineaments and leakage through confining layers in South Dakota. In Geohydrology of the Dakota Aquifer, Proceedings of the C. V. Theis Conference on Geohydrology, ed. D. G. Jorgensen and D. C. Signor, 121134. Worthington, Ohio: National Water Well Association.

Lawton, D. R., O. L. Goodenkauf, B. V. Hanson, and P. A. Smith. 1984. Dakota aquifers in eastern Nebraska: Aspects of water quality and use. In Geohydrology of the Dakota Aquifer, Proceedings of the C. V. Theis Conference on Geohydrology, ed. D. G. Jorgensen and D. C. Signor, 221-228. Worthington, Ohio: National Water Well Association.

Lennox, D. H., H. Maathuis, and D. Pederson. 1988. Region 13, Western Glaciated Plains. In Hydrogeology, ed. W. Back, J. S. Rosenshein, and P. R. Seaber, 115-128. Boulder Colorado: Geological Society of America.

Leonard, R. B., D. C. Signor, D. G. Jorgensen, and J. O. Helgesen. 1984. Geohydrology and hydrochemistry of the Dakota Aquifer, central United States. In Geohydrology of the Dakota Aquifer, Proceedings of the C. V. Theis Conference on Geohydrology, ed. D. G. Jorgensen and D. C. Signor, 229-237. Worthington, Ohio: National Water Well Association.

Ludvigson, G. A., R. Brenner, and A. Dogan. 1987. Preliminary evaluation of the provenance of and diagenetic environments of Dakota Formation sandstones in northwest Iowa. Geological Society of America, Abstract, with Programs 19, A231-A232.
Matheny, R. K., and P. J. Gerta. 1996. Environmental isotopic evidence for the origins of ground and surface water in a prairie discharge wetland. Wetlands 16, 109-122.

Macfarlane, P. A., 1995. The effect of river valleys and the upper Cretaceous aquitard on regional flow in the Dakota Aquifer in the central Great Plains of Kansas and southeastern Colorado. Current Research on Kansas Geology, Kansas Geological Survey Bulletin 238, 11-30.

O'Connor, T. M., 1987. A preliminary study of the hydrogeology of the Dakota formation in Douglas, Sarpy, and Washington counties, eastern Nebraska. M.S. thesis. Department of Geosciences. University of Nebraska-Lincoln.

Parkhurst, D. L. 1995. User's guide to PHREEQ A computer program for speciation, reaction path, advective transport, and inverse geochemical calculations. USGS Water Resources Investigations Report 95-4227.

Piper, A. M. 1944. A graphic procedure in the geochemical interpretation of water analyses. Transactions American Geophysical Union 25, 914-923.

Rutulis, M. 1984. Dakota aquifer system in the province of Manitoba. In Geohydrology of the Dakota Aquifer, Proceedings of the C. V. Theis Conference on Geohydrology, ed. D. G. Jorgensen and D. C. Signor, 22-26. Worthington, Ohio: National Water Well Association.

Siegel, D. J., 1991. Evidence for dilution of deep confined ground water by vertical recharge of isotopically heavy Pleistocene water. Geology 19, 436-443.

Siegel, D. J., and R. J. Mandle. 1984. Isotopic evidence for glacial meltwater recharge to the Cambrian-Ordovician aquifer, north-central United States. Quaternary Research 22, 328-335.

Stoder, R. L, F. E. Harvey, and D. C. Gosselin. 1999. Isotopic evidence for Pleistocene recharge in the Dakota Aquifer of Nebraska. Geological Society of America Annual Meeting, Denver, Colorado, October 25-28. Abstracts with Programs 31, no. 7: A-349.

Swenson, F. A. 1968. New theory of recharge to the artesian basin of the Dakotas. Geological Society of America Bulletin 79, 163-182.

Upham, W. 1895. The glacial Lake Agassiz. USGS Monograph 25.

Veatch, M. D. 1969. Ground water occurrence-movement-hydrochemistry - within a complex stratigraphic framework, Jefferson County, Nebraska. Ph.D. diss. Department of Geology, Stanford University, Palo Alto, California.

Whittemore, D. O., P. A. Macfarlane, J. H. Doveton, J. J. Butler, T-M. Chu, R. Bassler, M. Smith, J. Mitchell, and A. Wade. 1993. The Dakota Aquifer program annual report, FY92. Kansas Geological Survey Open-File Report 93-1. Lawrence, Kansas.

Witzke, B. J., and G. A. Ludvigson. 1994. The Dakota Formation in Iowa and the type area. In Perspectives on the Eastern Margin of the Cretaceous Western Interior Basin, ed. G. W. Shun, G. A. Ludvigson, and R. H. Hammond, 43-78. Boulder, Colorado: Geological Society of America Special Paper 287.

Witzke, B. J., G. A Ludvigson, J. R. Poppe, and R. L. Ravn. 1983. Cretaceous paleogeography along the eastern margin of the Western Interior Seaway, Iowa, southern Minnesota, eastern Nebraska and South Dakota. In Mesozoic Paleogeography of West-Central United States, ed. M. W. Reynolds and E. D. Dolly, 225-252. Denver Colorado: Rocky Mountain Section Society of Economic Paleontologists and Mineralogists. 